\title{
Contribution about the environment of El-Bayadh region in the southern-west of Algeria
}

\section{Djeldjeli Abdelhadi, Setti Mhamed and Amirech Louiza}

Sciences of Earth Faculty, Geography and Territorial Planning Department, USTHB Algiers

Correspondence Author: Djeldjeli Abdelhadi, Sciences of Earth Faculty, Geography and Territorial Planning Department, USTHB Algiers E-mail: abdelhadidjeldjli@yahoo.fr

Received date: 23 February 2018, Accepted date: 23 April 2018, Online date: 28 April 2018

Copyright: (C) 2018 Djeldjeli Abdelhadi et al. This is an open-access article distributed under the terms of the Creative Commons Attribution License, which permits unrestricted use, distribution, and reproduction in any medium, provided the original author and source are credited.

\begin{abstract}
This study is made for the purpose of giving an idea about the biotic components of a steppe zone characterized by a specific richness, the bibliographical synthesis revealed a special floristic wealth is found under three types of landscapes; rocky plateaus with herbaceous vegetation. The second is a shrub steppe and the third is the forest. Despite the scarcity of plants, the plants in the region are specific. The fauna of the region is characterized by a large diversity. In 108 vertebrate species, two birds and four mammals are at risk (Houbara bustard and the bald Ibis.) and (The Dorcas Gazelle, the dune gazelle, the Atlas Goundi and the Fennec are endangered. At the end of this study, it appears that the degradation of the steppe environment has forced migration to the city of El Bhayed as a solution.
\end{abstract}

Key words: biotic components, floristic, El Bhayed, The fauna, environmental degradation

\section{INTRODUCTION}

The arid steppes north of the Sahara occupy an area of $630,000 \mathrm{~km}^{2}$, between the isohyets of 100 and 400 mm of mean annual rainfall (MAR), from the Red Sea to the Atlantic Ocean. Physiognomically they may be subdivided into perennial grass, dwarf shrub, tall shrub, crassulescent, succulent and pulvinate steppes [17], Algeria has an ecological vulnerability resulting in fragile ecosystems to drought and desertification, unrestrained coastal erosion and a chronic water stress in some areas. The arid and steppe areas occupy about $32 \%$ of the land in Algeria, sensitive to desertification, composed of 20 million hectares of steppe and 12 million ha of pre-Saharan [10]. The action of wind erosion accentuates the desertification process; it varies depending on the plant cover. This type of erosion causes a soil loss of 100 to 250 tons/ha/year in cleared steppes [17]. According to [18], the natural resources of steppe region have undergone severe degradations due to the combined effects of a human and animal pressure increasing and of a worsening dryness on the ecosystems for several decades. These phenomena have contributed to increasing the fragility of ecosystems, reducing their capacity for regeneration and reduce their production potential. In the most vulnerable areas, overexploitation of renewable natural resources has the effect of favoring degradation processes leading to rapid spread of desertification [9], [19] whose major problem facing livestock in these areas is scarce and irregular food supply. Animal ruminant production in arid areas is characterized by periodic crises due to food shortages due to drought [18]. Knowledge, classification, characterization and conservation of different taxa are a global scientific priority for the assessment and management of biodiversity [7].

\section{MATERIEL AND METHODS}

Study area:

The territory of $\mathrm{El} \mathrm{Bayadh}$ borders in a space delimited by longitude $0{ }^{\circ}$ to $2^{\circ} \mathrm{E}$ and latitude $31^{\circ}$ to $34^{\circ} \mathrm{N}$. It divided into three geographical bands parallel to the Mediterranean Sea, successively from is north to south: the high steppe plains, the Saharan atlas zone and the pre-Saharan zone [8]. It is spread over an area of $71697 \mathrm{~km}^{2}$, that is $3 \%$ of the national territory. It is dominated by the three jewels of Jebel Amour chain Saharan Atlas, Boudergua 1873 meters, majestic by its mass with its remains of the optical post, El Ouastani 1878 meters and the great Ksel with 2008 meters. The relief of the Wilaya consists largely of: Mountains: $6.111 \mathrm{~km}^{2}$, Hills and foothills: $10.422 \mathrm{~km}^{2}$, Plains: $47.254 \mathrm{~km}^{2}$, Others: $7.910 \mathrm{~km}^{2}$. This region shows an ecological importance by its exceptional floristic and faunistic and economic wealth by the occupation of a herd exceeds the 1 million ovine heads.

The objective in this work is to highlight the current state of the environment in El Bayadh region. The average annual rainfall of El Bayadh region is relatively low; it represents $326 \mathrm{~mm}$ / year on average. The region of El Bayadh, given the morphology of its relief, presents two types of climate (semi-arid in the North and arid in the South) [8], [23].

Objective:

The present study is primarily a synthesis of floristic data followed by a synthesis of faunistic data well a study of the work was conducted in the region of El-Bayad. 


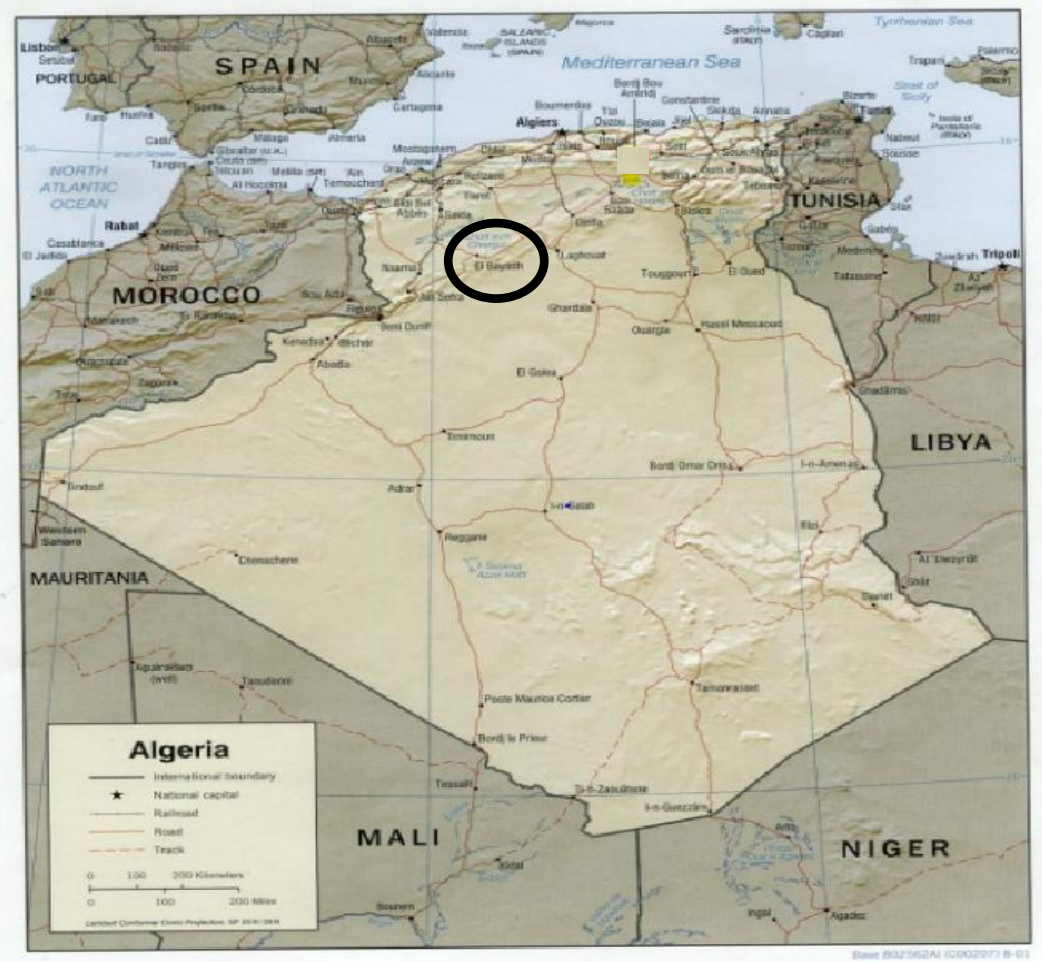

Fig. 1: Geographic position of El Bayadh [20]

\section{RESULTS AND DISCUSSION}

1- Flora of the El Bayadh region:

Generally, the vegetation of the steppe and Saharan zones consists of herbaceous and / or more or less shrubby plants. [13]. The same author in (1996 and 1998) recorded 211 species of spermaphytes, belonging to 38 botanical families or $31 \%$ of families identified in Algeria and $19,1 \%$ of the floristic diversity of the steppe routes of Algeria, Morocco and Tunisia grouped.

According to [3], there are 3 landscapes in the El Bayadh region, the first of which includes rocky plateaus with herbaceous vegetation with graminaceous vegetation. The second is a shrub steppe and the third is the forest. The first landscape is dominated by perennial perennial grasses such as alfa (Stipa tenacissima), sparte (Lygeum spartum) and some other less sociable species such as drinn (Stipa grostis pungens), zouaï (Stipa barbata syn. S. parviflora) and N'djem (Cynodon dactylon). The second landscape is structured by shrubs or sub-shrubs such as sagebrush (Artemisia herbaalba syn, Seriphidium herba-album, A.campestris, A. monosperma), arfej (Rhanterium suaveolens), rem't (Hammada scoparia). ), baguel (Hammada schmittiana), chobrog (Noaea mucronata), helianthes (Heiianthemum hirtum, H. Iipii, H. virgatum, H. cinereum), ajrem (Anabasis sp.) and serr (Atractylis serratuloides syn A. phaeolepis). The third landscape is located on the Saharan Atlas mountains and is mainly composed of the Aleppo pine from the green dam project [1].

In our region the area of rangelands represents $86 \%$ of the total area. According to [8] the steppe space is subject to degradation affecting $80 \%$ of the total area. It is the most degraded steppic part of the Algerian steppe, this situation directly influences faunistic diversity and human life in this region.

2- $\quad$ Wildlife of El Bayadh region:

In this part invertebrates and vertebrates are developed.

\section{1- Invertebrates of El Bayadh Region:}

The Invertebrates of the El Bayadh region is little studied, it is worth noting the work of [21] on the Arachnids. Meanwhile for Insects and more specifically for Orthopteroids, The work of [6] should be noted.

The class of arachnids is essentially represented by the orders of Scorpionnida. The species present are mainly Buthus occitanus tunetanus (HERBST, 1800), Antroctonus australis (HECTOR and KOCH, 1839) and Antroctonus aeneas $(\mathrm{KOCH}, 1839)$. [21]. Regarding the class of insects, [6] reported the presence of 3 orders. The Blattodea are represented by Heterogamodes ursina (BURMEISTER, 1838) and Heterogamodes bolivari (ADEIUNG, 1914). The second order of Mantodea is represented by a single species Eremiaphila denticollis (LUCAS, 1855). For the third order of the Orthoptera, he noted the presence of six species (Duroniella lucasi (BOIVAR, 1881), Dociostaurus maroccanus (THUNBERG, 1815), Gryllus burdigalensis (LATREITTE, 1804).

\section{2- Amphibians of the El Bayadh region:}

Amphibians are poorly studied in the El Bayadh area. According to the work of [16] and [15], only three species are noted. These species are listed in the table (1)

Table 1: List of Amphibians in the El Bayadh Region

\begin{tabular}{|l|l|l|l|}
\hline Orders & Families & Species & Common name in French \\
\hline \multirow{3}{*}{ Anoures } & \multirow{2}{*}{ Bufonidae } & Bufo viridis (Laurenti, 1768) & Crapaud vert \\
\cline { 2 - 4 } & & Bufo mauritanicus (Schlegel, 1841) & Crapaud de Maurétanie \\
\cline { 2 - 4 } & Ranidae & Ranaridibunda (Pallas, 1771) & Grenouille rieuse \\
\hline
\end{tabular}

\section{3- Reptiles of El Bayadh region:}

Reptiles in the El Bayadh area are poorly studied. Since the completed list of [15] in 1989, no work has been done on reptiles until 1995. [16] in 1995 completes the list of this class. These authors report the presence of three orders. The order of Sauriens is the best represented with 15 species divided between 7 families. Followed by the order of the Ophidians represented by 6 species divided between 2 families. Then the order of the Testudines least represented by a single species. These results are shown in the table (2). 
Citation: Djeldjeli Abdelhadi, Setti Mhamed and Amirech Louiza, 2018. Contribution about the environment of El-Bayadh region in the southern-west of Algeria. Advances in Environmental Biology., 12(4): 1-5.

Table 2 -Reptile of the El Bayadh region

\begin{tabular}{|c|c|c|c|}
\hline Orders & Families & Species & Common name in French \\
\hline Testudines & Testudinidae & Testudo graeca (Linné, 1758) & Tortue mauresque \\
\hline \multirow{20}{*}{ Squamata } & \multirow{4}{*}{ Colubridae } & Rhagerhis moilensis (Reuss, 1834) & Couleuvre moilensis \\
\hline & & Malpolon monspessulanus (Hermann, 1804) & Couleuvre de Montpellier \\
\hline & & Macroprotodon cucullatus (G.De St-Hilaire, 1827) & Macroprotodon cucullatus \\
\hline & & Lytorhynchus diadema (D, Bibron \&Duméril, 1854) & Couleuvre diadème \\
\hline & Varanidae & Varanus griseus (Daudin, 1803) & Varan du désert \\
\hline & Elapidae & Naja haje (Linnaeus, 1758) & Cobra égyptien \\
\hline & Chamaeleonidae & Chamaeleo chamaeleon (Linnaeus, 1758) & Caméléon commun \\
\hline & \multirow[b]{2}{*}{ Viperidae } & Cerastes cerastes (Linnaeus, 1758) & Vipère à cornes \\
\hline & & Cerastes vipera (Linnaeus, 1758) & Vipère céraste \\
\hline & \multirow{3}{*}{ Agamidae } & Uromastyx acanthinura (Bell, 1825) & Fouette-queue \\
\hline & & Agama impalearis (Boettger, 1874) & Agama impalearis \\
\hline & & Trapelus mutabilis (Merrem, 1820) & Trapelus mutabilis \\
\hline & \multirow{3}{*}{ Lacertidae } & Mesalina olivieri (Audouin, 1829) & Mesalina d'olivier \\
\hline & & Mesalina guttulata (Lichtenstein, 1823) & Mesalina à gouttelettes \\
\hline & & Mesalina rubropunctata (Lichtenstein, 1823) & Mesalina à points rouges \\
\hline & Scincidae & Scincopus fasciatus (Peters, 1864) & Scinque de Géry ville \\
\hline & \multirow[b]{2}{*}{ Phyllodactylidae } & Tarentola mauritanica (Linnaeus, 1758) & Tarente de Maurétanie \\
\hline & & Ptyodactylus oudrii (Lataste, 1880) & Gecko \\
\hline & \multirow[b]{2}{*}{ Gekkonidae } & Stenodactylus petrii (Anderson, 1896) & Gecko de pétri \\
\hline & & Stenodactylus sthenodactylus (Lichtenstein, 1823) & Gecko de Stenodactylus \\
\hline
\end{tabular}

\section{4- Birds of El Bayadh region:}

The table (3) groups the results of avian species recorded by [11], [12] and [15] in the El Bayadh region.

Table 3: List of birds from El Bayadh region

\begin{tabular}{|c|c|c|c|}
\hline Orders & Families & Species & Common name in French \\
\hline \multirow{2}{*}{ Pelecaniformes } & Ardeidae & Bubulcus ibis (Linnaeus, 1758) & Héron garde-bœufs \\
\hline & Threskiornithidae & Geronticus eremita (Linnaeus, 1758) & L'Ibis chauve \\
\hline Ciconiiformes & Ciconiidae & Ciconia ciconia (Linnaeus, 1758) & Cigogne blanche \\
\hline \multirow{4}{*}{ Accipitriformes } & \multirow{4}{*}{ Accipitridae } & Circus aeruginosus(Linnaeus, 1758) & Busard des roseaux \\
\hline & & Circus pygargus(Linnaeus, 1758) & Busard cendré \\
\hline & & Circaetus gallicus (Gmelin, 1788) & Circaète Jean-le-Blanc \\
\hline & & Buteo rufinus (Cretzschmar, 1829) & Buse féroce \\
\hline \multirow{2}{*}{ Falconiformes } & \multirow{2}{*}{ Falconidae } & Falco biarmicus (Temminck, 1825) & Faucon lanier \\
\hline & & Falco tinnunculus (Linnaeus, 1758) & Faucon crécerelle \\
\hline \multirow{30}{*}{ Passeriformes } & Emberizidae & Emberiza calandra (Linnaeus, 1758) & Bruant proyer \\
\hline & Passeridae & Passer hispaniolensis (Temminck 1820) & Moineau espagnol \\
\hline & Passeridae & Passer domesticus (Linnaeus, 1758) & Moineau domestique \\
\hline & Corvidae & Corvus corax (Linnaeus, 1758) & Grand Corbeau \\
\hline & Laniidae & Lanius excubitor (Linnaeus, 1758) & Pie-grièche grise \\
\hline & Laniidae & Lanius senator (Linnaeus, 1758) & Pie-grièche à tête rousse \\
\hline & Leiothrichidae & Turdoides fulva (Desfontaines, 1789) & Cratérope fauve \\
\hline & Phylloscopidae & Phylloscopus trochilus (Linnaeus, 1758) & Pouillot fitis \\
\hline & Phylloscopidae & Phylloscopus collybita (Vieillot, 1817) & Pouillot véloce \\
\hline & Scotocercidae & Scotocerca inquieta (Cretzschmar, 1830) & Dromoïque du désert \\
\hline & Sylviidae & Sylvia communis (Latham, 1787) & Fauvette grisette \\
\hline & Sylviidae & Sylvia cantillans (Pallas, 1764) & Fauvette passerinette \\
\hline & Sylviidae & Sylvia conspicillata $($ Temminck, 1820$)$ & Fauvette à lunettes \\
\hline & Sylviidae & Sylvia deserti (Loche, 1858) & Fauvette du désert \\
\hline & Acrocephalidae & Hippolais polyglotta (Vieillot, 1817) & Hypolaïs polyglotte \\
\hline & Muscicapidae & Ficedula albicollis (Temminck, 1815) & Gobe-mouche à collier \\
\hline & Muscicapidae & Cercotrichas galactotes $($ Temminck, 1820$)$ & Agrobate roux \\
\hline & Muscicapidae & Oenanthe oenanthe (Linnaeus, 1758) & Traquet motteux \\
\hline & Muscicapidae & Oenanthe leucura (Gmelin, 1789) & Traquet rieur \\
\hline & Muscicapidae & Phoenicurus phoenicurus (Linnaeus, 1758) & Rougequeue à front blanc \\
\hline & Muscicapidae & Phoenicurus ochruros (Gmelin, 1774) & Rougequeue noir \\
\hline & Muscicapidae & Oenanthe hispanica (Linnaeus, 1758) & Traquet oreillard \\
\hline & Motacillidae & Motacilla alba (Linnaeus, 1758) & Bergeronnette grise \\
\hline & Motacillidae & Motacilla flava (Linnaeus, 1758) & Bergeronnette printanière \\
\hline & Hirundinidae & Delichon urbicum (Linnaeus, 1758) & Hirondelle de fenêtre \\
\hline & Hirundinidae & Hirundo rustica (Linnaeus, 1758) & Hirondelle de cheminée \\
\hline & Alaudidae & Eremophila alpestris (Linnaeus, 1758) & Alouette hausse-col \\
\hline & Alaudidae & Melanocorypha calandra (Linnaeus, 1758) & Alouette calandre \\
\hline & Alaudidae & Ammomanes deserti (Lichtenstein, 1823) & Ammomane isabelline \\
\hline & Alaudidae & Ammomanes cinctura (Gould, 1839) & Ammomane élégante \\
\hline Coraciiformes & Meropidae & Merops apiaster (Linnaeus, 1758) & Guêpier d'Europe \\
\hline Bucerotiformes & Upupidae & Uрира ерорs (Linnaeus, 1758) & Huppe fasciée \\
\hline Galliformes & Phasianidae & Coturnix coturnix (Linnaeus, 1758) & Caille des blés \\
\hline \multirow[t]{2}{*}{ Pterocliformes } & Pteroclidae & Pterocles alchata (Linnaeus, 1766) & Ganga cata \\
\hline & Pteroclidae & Pterocles orientalis (Linnaeus, 1758) & Ganga unibande \\
\hline Apodiformes & Apodidae & Apus affinis (Gray, 1830) & Martinet des maisons \\
\hline
\end{tabular}


Citation: Djeldjeli Abdelhadi, Setti Mhamed and Amirech Louiza, 2018. Contribution about the environment of El-Bayadh region in the southern-west of Algeria. Advances in Environmental Biology., 12(4): 1-5.

\begin{tabular}{|l|l|l|l|}
\hline & Apodidae & Apus pallidus (Shelley, 1870) & Martinet pâle \\
\hline \multirow{3}{*}{ Strigiformes } & Tytonidae & Tyto alba (Scopoli, 1769) & Chouette effraie \\
\cline { 2 - 4 } & Strigidae & Bubo bubo (Linnaeus, 1758) & Hibou grand-duc \\
\cline { 2 - 4 } & Strigidae & Athene noctua (Scopoli, 1769) & Chevêche d'Athéna \\
\hline \multirow{4}{*}{ Columbiformes } & Columbidae & Columba livia (Gmelin, 1789) & Pigeon biset \\
\cline { 2 - 4 } & Columbidae & Streptopelia turtur (Linnaeus 1758) & Tourterelle des bois \\
\cline { 2 - 3 } & Columbidae & Streptopelia senegalensis (Linnaeus 1766) & Tourterelle maillée \\
\cline { 2 - 3 } & Columbidae & Streptopelia decaocto (Frivaldszky, 1838) & Tourterelle turque \\
\hline
\end{tabular}

According to the census of [2]. In 2006, birdlife in the El bayadh region reached 53 species of birds distributed among 24 families and 10 orders. The order Passeriformes is the most represented in number of species with 30 species. In this list, there are more than 2 species threatened to disappear such as the houbara bustard and the bald Ibis.

\section{5- Mammals of El Bayadh Region:}

The results of the mammalian species found by [15], [14] and [16] are shown in the table (4)

Table 4: List of Mammals in El Bayadh Region

\begin{tabular}{|c|c|c|c|}
\hline Orders & Families & Species & Common name in French \\
\hline \multirow{9}{*}{ Artiodactyla } & \multirow[t]{2}{*}{ Bovidae } & Gazella dorcas(Linnaeus, 1758) & Gazelle dorcas \\
\hline & & Gazella leptoceros(F. Cuvier, 1842) & Gazelle leptocère \\
\hline & Suidae & Sus scrofa (Linnaeus, 1758) & Sanglier \\
\hline & Felidae & Felis silvestris (Schreber, 1777) & Chat sauvage \\
\hline & \multirow[t]{2}{*}{ Mustelidae } & Ictonyx libyca (Hemprich \&Ehrenberg, 1833) & Zorille de Libye \\
\hline & & Mellivora capensis (Schreber, 1776) & Zorille du Cap \\
\hline & \multirow{3}{*}{ Canidae } & Canis aureus (Linnaeus, 1758) & Chacal doré \\
\hline & & Vulpes vulpes (Linnaeus, 1758) & Renard roux \\
\hline & & Vulpes zerda (Zimmermann, 1780) & Fennec \\
\hline \multirow{3}{*}{ Chiroptera } & Vespertilionidae & Pipistrellus kuhlii(Natterer in Kuhl, 1817) & Pipistrelle de Kuhl \\
\hline & \multirow[t]{2}{*}{ Rhinopomatidae } & Rhinolophus blasii(Peters, 1866) & Chauve-souris \\
\hline & & Rhinopoma hardwickii (Gray, 1831) & Petit rhinopome \\
\hline \multirow[b]{2}{*}{ Erinaceomorpha } & \multirow[b]{2}{*}{ Erinaceidae } & Atelerix algirus (Lereboullet, 1842) & Hérisson d'Algérie \\
\hline & & Paraechinus aethiopicus (Ehrenberg, 1833) & Hérisson du désert \\
\hline Lagomorpha & Leporidae & Lepus capensis(Linnaeus, 1758) & Lièvre du Cap \\
\hline Macroscelidea & Macroscelididae & Elephantulus rozeti(Duvernoy, 1833) & Rats à trompe \\
\hline \multirow{14}{*}{ Rodentia } & Sciuridae & Atlantoxerusgetulus(Linnaeus, 1758) & Écureuil de Berberie \\
\hline & Gliridae & Eliomys quercinus (Linnaeus, 1758) & Lérot commun \\
\hline & Ctenodactylidae & Ctenodactylus gundi(Rothmann, 1776) & Goundi de l'Atlas \\
\hline & \multirow[b]{2}{*}{ Dipodidae } & Jaculus jaculus (Linné, 1758) & Gerboise des steppes \\
\hline & & Jaculus orientalis (Erxleben, 1777) & Grande gerboise d'Égypte \\
\hline & \multirow{9}{*}{ Muridae } & Dipodillus campestris(Loche, 1867) & Gerbille champêtre \\
\hline & & Gerbillusnanus (Blanford, 1875) & Gerbille du Baluchistan \\
\hline & & Gerbillus pyramidum(Geoffroy, 1825) & Grande gerbille \\
\hline & & Meriones libycus $($ Lichtenstein, 1823) & Mérione libyen \\
\hline & & Meriones shawi(Duvernoy, 1842) & Mérione de shaw \\
\hline & & Mus musculus (Linnaeus, 1758) & Souris grise \\
\hline & & Pachyuromys duprasi(Lataste, 1880$)$ & Gerbille à queue en massue \\
\hline & & Psammomys obesus (Cretzschmar, 1828) & Rat du sable \\
\hline & & Rattus rattus(Linnaeus, 1758) & Rat noir \\
\hline Soricomorpha & Soricidae & Crocidurawhitakeri (Winton, 1898) & Musaraigne de Whitaker \\
\hline
\end{tabular}

According to [2] The Dorcas Gazelle (Gazella dorcas), the dune gazelle (Gazella leptoceros), the Atlas Goundi (Ctenodactylus gundi) and the Fennec (Fennecus zerda) are endangered species. This situation has led the state to make protection programs and projects of multiplication and reintroduction. Only two species are protected in a multiplication reserve project (the Dorcas Gazelle and the dune gazelle) in the Brezina region.

3- $\quad$ The migration of the companions to the town of El Bayadh:

The steppe population represented 25\% of the total Algerian population. Most of the population in scattered areas of the steppe has become semi-sedentary. Pastoralists have modified their production system by combining cereal cultivation, breeding and sedentarization. The environmental degradation in this area is forcing pastoralists and their families to migrate to the city of El Bayadh. In all the world the unfavorable condition influences the distribution of the inhabitants [22]. The evolution of the number of inhabitants of El Bayadh is in the following figure (2). 


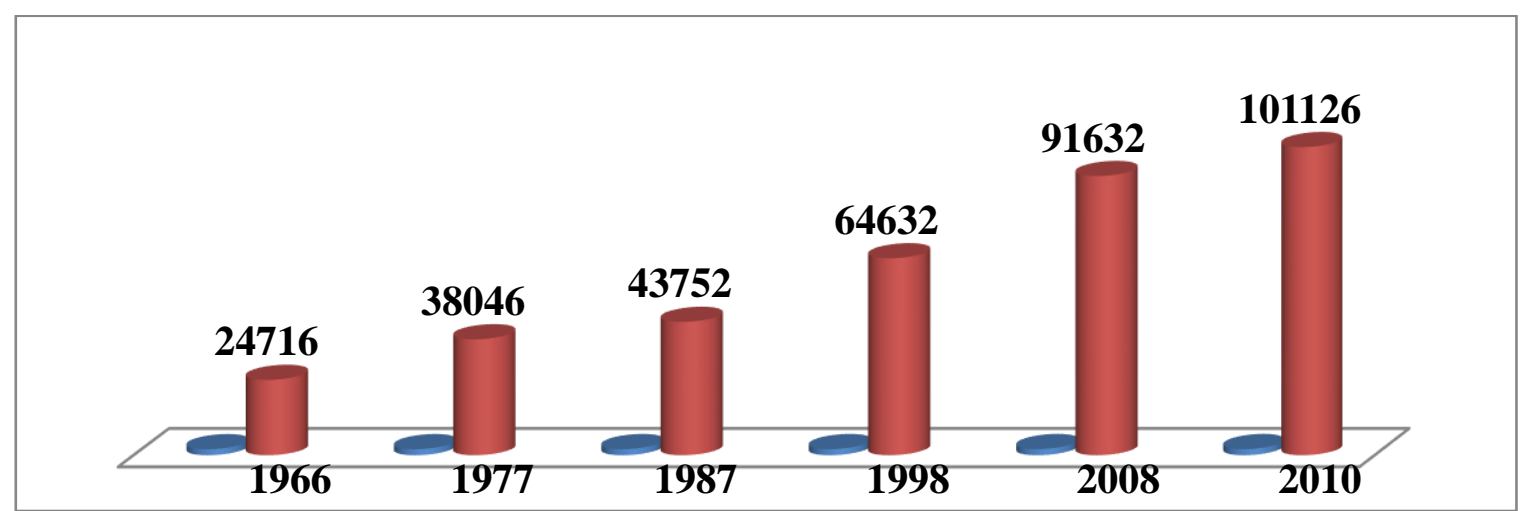

Fig. 2: Evolution of number of inhabitants from 1966 to 2010 in the municipality of El Bayadh

In the city of El Bayadh the natural birth reaches 3.1\%, while the growth rate of this city is exceeded $33.93 \%$. The unfavorable conditions of life in the degraded steppe favor the internal migration of the population towards the city of El Bayaed. About $30 \%$ of the population had to migrate between 1966 and 2010 , in search of better living and working conditions.

Conclusion:

From this study there is a large list of animal species at risk of disappearing. This list bears the two birds Houbara Bustard and Bald Ibis four mammals are the Dorcas Gazelle, the dune gazelle, the Atlas Goundi and the Fennec. This state requires immediate intervention by protection programs and multiplication and reintroduction projects before it is too late. Diversity in the Algerian steppe remains unscathed; it is in need of new research. For example on nematodes, we find only the work of [5] in the region of M'sila. The same for work on insects, they are rare in the El Bayadh region and also in all Algerian steppes except the work of [4] in Ghardaya.

With regard to population migration from steppe areas to cities such as the case of the city of El Bayadh, remains the result of the degradation of the environment.

\section{REFERENCES}

[1] A.N.A.T., 2003. Etude prospective et de développement de la wilaya d'El Bayadh. Ed. Agence nationale d'aménagement du territoire, Tlemcen, p: 35.

[2] N.N., 2006. Inventaire de la diversité biologique de la wilaya d'El Bayadh. Ed. Direction de l'environnement, Min. aménag. terr. Environ., El Bayadh, p : 36.

[3] AIDOUD, A., LE FLOCHE. et H.N. LE HOUEROU, 2006. Les steppes arides du Nord de l'Afrique. Sécheresse, 17(1-2): 19-30.

[4] BABA AISSA, N., S. BOUKRAA, S. BOUKRAA, Z. LOUNACI AND S. DOUMANDJ, 2017. A preliminary study of biodiversity and bio-ecology of Brachyceran flies (Insecta: Diptera) in oases of Ghardaïa Advances in Environmental Biology, 11(3): 81-88.

[5] BERRABAH, D., F. HOCEINI, D. BABAALI, B. DOUMANDJI-MITICHE, S. DOUMANDJI, D. NEBIH and A. ABDESSAMAD, 2016. The First Study of The Nematode Communities Associated With Medicinal Plants In Algeria, Advances in Environmental Biology, 10(9): 246-253.

[6] CHOPARD, L., 1943. Orthopteroïdes de l'Afrique du Nord. Ed. Larose, Paris, Coll.Faune de l'empire français, I, p: 450.

[7] COTTERILL, F.P.D., 1995. Systematics, biological knowledge and environmental conservation. Biodiversity and Conservation, 4 : 183-205.

[8] EL ZEREY WAEL, BACHIR SALAH EDDINE BOUIADJRA1, MOHAMED BENSLIMANE ET KHALLADI MEDERBAL, 2009. L'écosystème steppique face à la désertification : cas de la région d'el bayadh, algérie. VertigO, 9(2): 1-12.

[9] FLORET, C., E. LE FLOC'H and R. PONTANIER, 1992. Perturbation anthropique et aridification en zone présaharienne in : l'aridité une contrainte de développement, caractérisation, réponses biologiques et stratégie de sociétés. Eds LE Floc'h E., Grouzis M., Cornet A. \& Bille J.C., Ed. OROSTOM Paris, pp: $449-463$.

[10] GHAZI, Z., 2012. Politique de renouveau rural : impacts et perspectives d'évolution, Séminaire sur la mise en place d'un dispositif de Formation au Développement Rural, ITMAS Ain Temouchent du 11 au 13 juin pp: 8-13.

[11] HEIM DE BALSAC, H., 1936. Biogéographie des mammifères et des oiseaux de l'Afrique du Nord de la France et de la Belgique. Bull. Bio., Paris, p: 447.

[12] HEINZEL, H., R. FITTER and J. PARSLOW, 2004. Guide Heinzel des oiseux d'Europe d'Afrique du nord et moyen orient, Ed. Delachaux et Niestle, Paris p: 384.

[13] KAABECHE, M., 2000. Guide des habitats arides et saharien (Typologie physiologique de la végétation d’Algérie. Ed. Direction générale for. (D.G.F), Alger, p: 56.

[14] KOWALSKI, K. and B. RZEBIK-KOWALSKA, 1991. Mammals of Algeria. Ed. Ossolineum, Wroclaw, p: 353

[15] LE BERRE, M., 1989. Faune du Sahara - Mammifères. Ed. Lechevalier - R. Chabaud, Paris, coll. 'Terres africaines', T. 2 : 332.

[16] LE HOUÉROU, H.N., 2002. Biogeography of the arid steppeland north of the Sahara. J. Arid Environ, (48): 103-128.

[17] LE HOUEROU, H.N., 1995. Bioclimatologie et biogéographie des steppes arides du Nord de l'Afrique. Options Méditer. Ser. B Études et Recherches, 10 : 396.

[18] NEDJIMI, B. and M. HOMIDA, 2006. Problématique des zones steppiques algériennes et perspectives d'avenir. Revue du Chercheur, 4 : $13-19$.

[19] NEFZAOUI, A. and A. CHERMITI, 1991 - Place et rôles des arbustes fourragers dans les parcours de zones arides et semi-arides de la Tunisie. Options méditerranéennes. CIHEAM .Montpellier. Série séminaires n $16: 119-125$.

[20] SAIFI, M., F.Z. BERROUANE, F. BENSAADA, S. DOUMANDJ, 2017. Preliminary study of necrophagous Diptera associated with boar corpse (Sus scrofa) in a semi environment in eastern Algeria: Implications in forensic entomology Rev Advances in Environmental Biology, $11(3)$ : 1-8.

[21] VACHON, A., 1952. Les scorpions de l'Algérie. Ed. Institut Pasteur d'Algérie, Alger, p: 452.

[22] WAQAR AHMAD and TINGWU YAN, 2017. Effect of Non-farm income on Poverty Status Among rural farmers in Pakistan (A Case Study of Tehsail Bahrain District Swat), Rev Advances in Environmental Biology, 12(1): 6-10.

[23] http://www.dsp-elbayadh.dz/index.php/carte-interactive-3/presentation-de-la-wilaya d'elbayedh 